\title{
研究室紹介 \\ 大阪電気通信大学 工学部 機械工学科 流体工学研究室
}

\author{
山本 剛宏*
}

(原稿受理：2021 年 5 月 6 日)

\section{1. はじめに}

筆者は 2016 年 4 月に大阪電気通信大学工学部機械工学科 に着任し，流体工学研究室 ${ }^{1)}$ を担当することとなった。 それ まで当研究室はニュートン流体の流動を対象とした研究室で あったが，筆者の着任後，非ニュートン流体・複雑流体の流 動を扱うようになった。そのような訳でレオロジー関連分野 を主な研究対象とする研究室としての歴史は浅いが, ここで は, 筆者のこれまでの研究背景も含めて当研究室の紹介をさ せて頂く

\section{2. 研究室の沿革}

筆者は 1990 年に大阪大学工学部産業機械工学科（当時）に おいて, 中村喜代次教授のもとで卒業研究として非ニュート ン流体の流動現象の研究を始めて以来, 非ニュートン流体・複 雑流体の流動現象に関する研究を続けてきた。中村先生が退 官されてからは森教安教授が研究室を引き継がれ，筆者は准 教授として森先生のもとで教育・研究を続けてきた。この間, 高分子流体（粘弾性流体），液晶高分子，界面活性剂水溶液 (ミセル分散系)，コロイド粒子分散系などの複雑流体を研究 対象として, 実験と数值計算の両面で流動メカニズムの解析 を行った。 そこでの経験と知識を持ち込み, 当研究室の立ち 上げに取り掛かった。

大阪電気通信大学工学部は京阪本線・寝屋川市駅から徒歩 約 7 分と交通の便の良いロケーションにある寝屋川キャンパ スにあり, 現在, 同キャンパスでは, 新しい研究棟 (OECU イ ノベーションスクエア, OECU は大学名英文表記の略称）の 建設が進められている。新研究棟の第 1 期工事が 2020 年 6 月 に竣工し，当研究室も同年 7 月にそこへ引越しをした。第 1 期工事では全体の西側半分が完成し, 現在残り半分の建設中 である（2023 年完成予定）。新研究棟は「オープンな研究室 で, 専門外の新たな学問に触れ, 研究のイノベーションを起 こしたい」というオープンド・キャンパス（オープンキャン パスではない）のコンセプトのもとに設計された，研究棟の 中央にはパサージュと名付けられた通路が東西に通り，人の 往き来が促進されるような構造になっている (Fig. 1)。そし て, 研究室間の仕切りはなく, プロジェクトルームや教員室 の通路側はガラス張りである (Fig. 2) . 実際に新棟で研究活 動を始めると，ややオープンすぎる印象は否めないが，斬新

* $\bar{\top}$ 572-8530 大阪府寝屋川市初町 $18-8$

E-mail: tyamamot@osakac.ac.jp, Tel: +81-72-812-3392

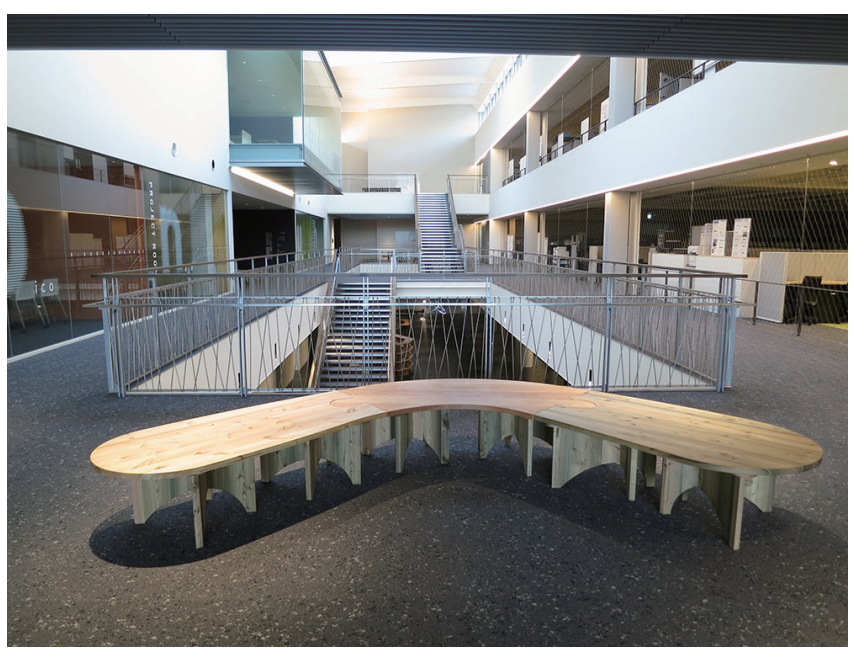

Fig. 1 パサージュを望む風景. 本稿執筆時点では半分のみ完成している. 完成時には奥行き方向に約 2 倍の長さになる

なコンセプトの空間によって新たなケミストリーが期待でき るのかどうか様子を見ていきたい. 現在, 当研究室はこのよ うな環境で教育・研究活動を推進中である.

\section{3. 現在の研究について}

2021 年度の研究室所属学生は学部生 11 名, 大学院博士前 期課程学生 1 名, 大学院博士後期課程学生 1 名である. 毎年 10 名前後の 4 年生が卒研生として配属されるが, その中から 大学院に進学する者は 1,2 名である。私立大学の場合，一般 に, 国公立大学に比べて大学院進学率は低いのだが, 本学の 場合はさらに低い方であると言わざるを得ない，したがって， 毎年 4 月になると, 全く新しい研究室に生まれ変わったよう なフレッシュな感覚を味わえるのだが，新陳代謝が良すぎる のも考えもので, 毎年, 研究室としての知識がほぼリセット される中, 研究を継続しノウハウを蓄積していく方策を編み 出すために苦労している（一方，筆者自身の脳味噌は，逆に 細胞活動の不活性化が進み, そのために記憶減衰の速度が加 速され，記憶が頻繁にリセットされて苦労している），

実験は研究棟にある学科共同の実験室（Fig. 3）と実験棟に ある機械工学実験の授業で使用している部屋の空きスペース で行っている。また, 幸いなことに, 着任の翌年にメカトロ ニクス基礎研究所（学内の研究組織・兼任）の共同研究設備 としてレオメーター（Anton Paar, MCR302）を購入して頂き, 

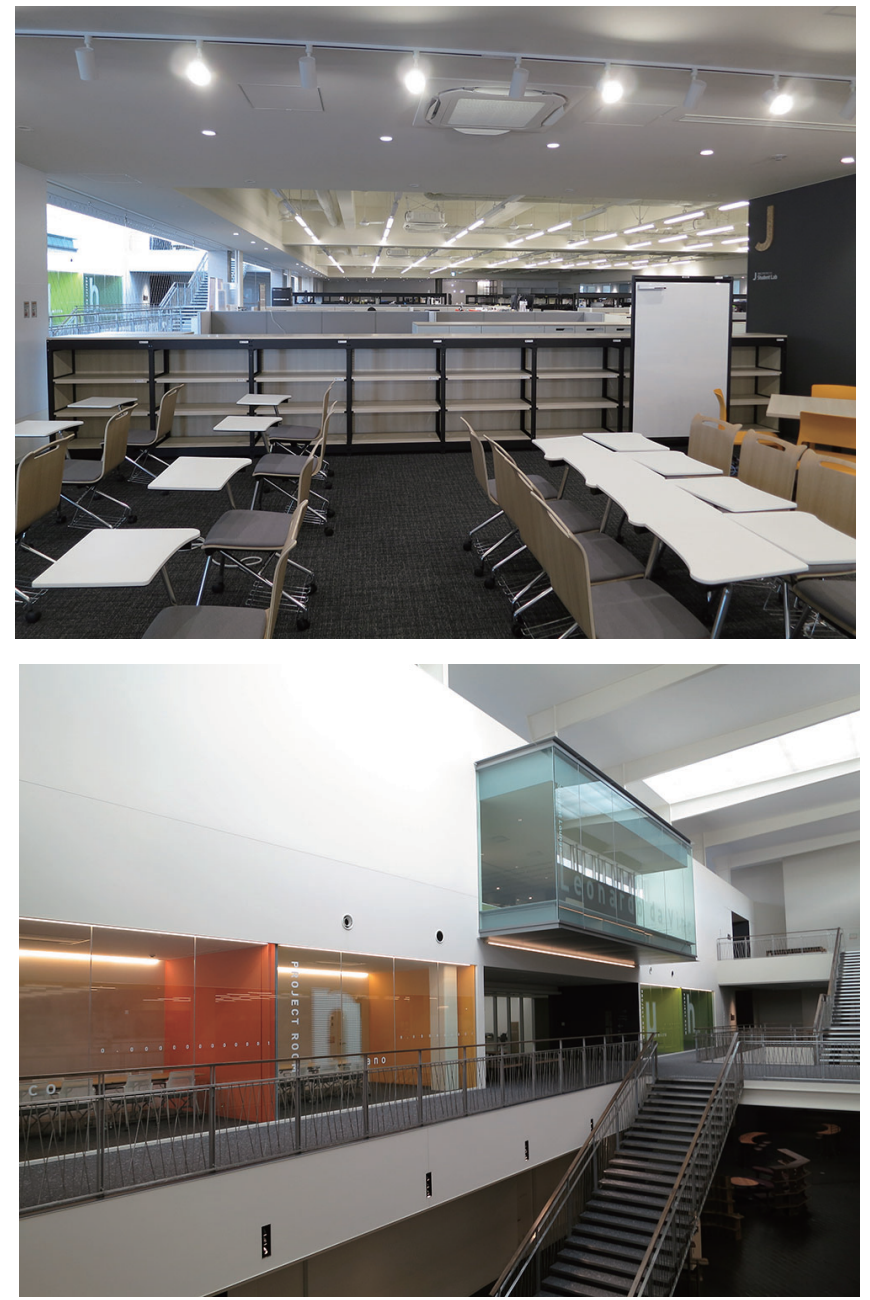

Fig. 2 OECU イノベーションスクエアの研究室エリア (上) とプロジェク トルーム (下) . 研究室エリアの手前は学生サロンで奥が各研究室. プロジェクトルームは予約をすれば学生・教員が自由に使用できる.

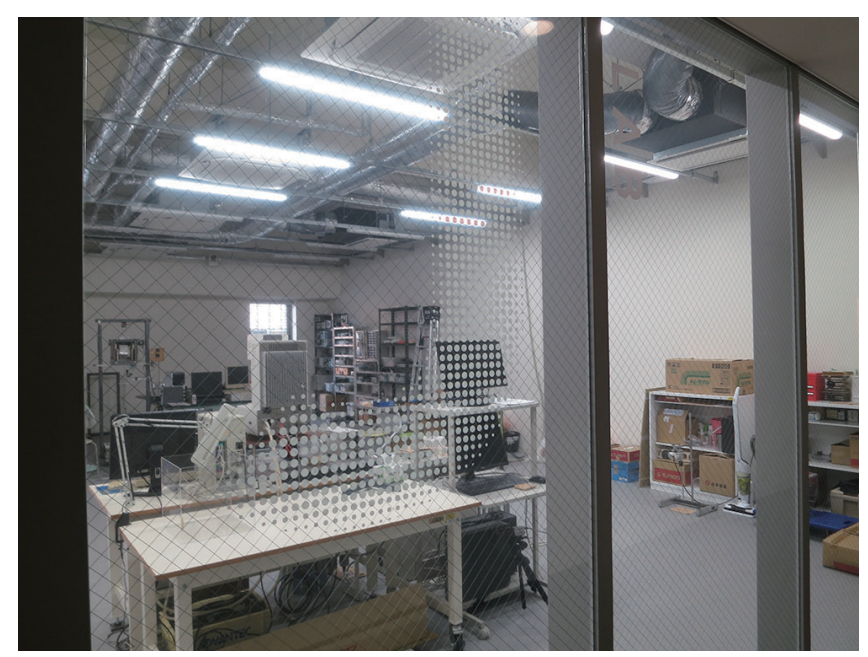

Fig. 3 機械工学科実験室.

研究に活用している. 計算には, 研究室所有のハイパフォーマ ンスコンピュータ 12 台を使用している。計算機は筆者や学生 が寝ている間も日々計算を続けている。 ご褒美として，新棟 に移ってからは常時冷房の効いた部屋で働いてもらっている. 現在行っている研究として, 実験関連では（a）非ニュート
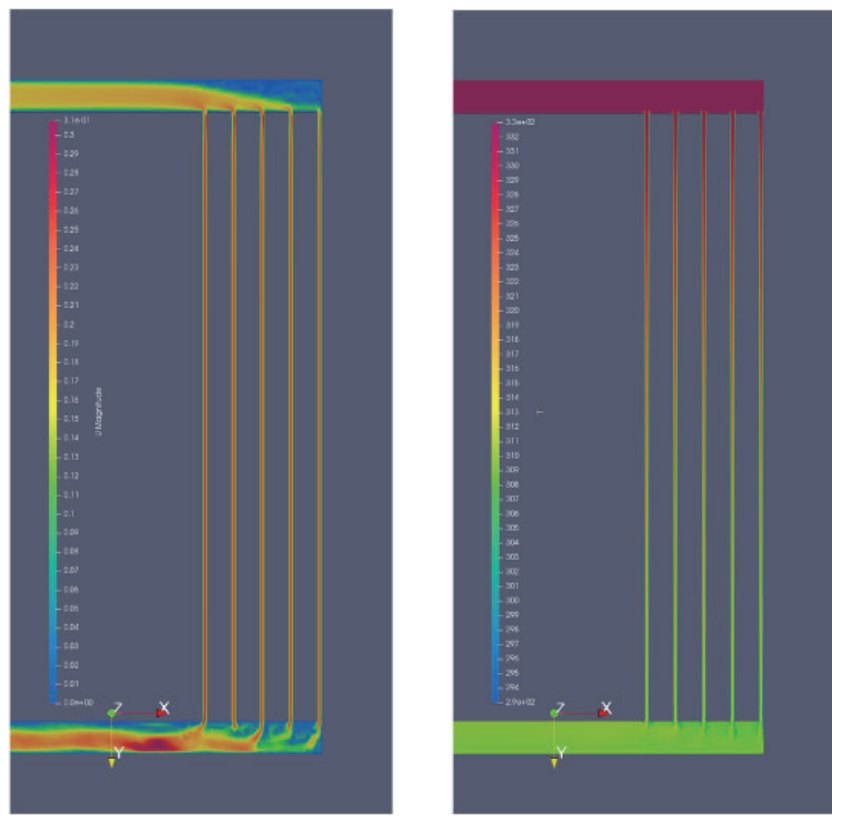

Fig. 4 ナノ流体の数值熱流動解析の例：速度分布（左）と温度分布（右）

ン流体の跳水現象，（b）粘弾性流体への物体貫入時のキャビ ティ発生などの研究を, 数值計算関連では (c) フロック形成 流体の数值解析モデルの開発 ${ }^{2,3)}$, (d) 生物系粒子分散系の流 動誘起構造 4-6)，(e）十ノ流体の熱流動解析 7) などの研究を 行っている. 以下に各研究テーマについて簡単に紹介する. (a) 開流路内の自由表面流れにおいて，流れが減速するときに液 面高さが急激に上昇する跳水現象が現れる。粘塑性流体のよ うな非ニュートン流体のレオロジー特性の跳水現象への影響 について調べている.（b）粘弾性流体に球を貫入した際に流体 中に発生するキャビティと流体のレオロジー特性との関係を 解析している. (c) ナノファイバーなどのフロックの生成・破 壊をフロックサイズ分布のポピュレーションバランス方程式 を用いて表現し，フロック形成流体の流動解析を行うための 数理解析モデルの検討と複雑な流れ場への適用の検討を行っ ている. (d) 走光性微細藻類のように走性を有する微生物の分 散流体では，周囲環境からの刺激によって微生物が運動する ことで，ある種の流動誘起構造が形成される。ここでは，生 物の走性に基づく能動粒子分散系の流体内部構造の形成メカ ニズムの解析を行っている. (e) ベース流体にナノスケールの 金属粒子を添加することにより，熱輸送流体の熱特性が向上 する。その一方で粘度上昇により流動に要する動力が上昇す るため, 適切な使用条件の把握が必要となる。ここでは, 流 動による粒子濃度分布や粒子形状の違いによる熱効率への影 響を数值解析している（Fig. 4）

\section{4. おわりに}

こちらに着任した際には，学内に複雑流体の流動を主とし て扱う研究室はなく，レオロジー不毛の地にやって来た感が あったが, しばらくしてみると, 学内には化学工学や食品工 学の研究室もあり, レオロジー学会でお会いすることはなかっ たがレオロジーに関係の浅くはない研究者も多いことがわかっ た. 改めてレオロジーの守備範囲の広さを感じた次第である. また, 2020 年には機械工学科に大阪市立大学から吉岡真弥先 
生が来られ, 同じ学科に固体分野と流体分野のレオロジスト が揃うことになった。引き続きレオロジー不毛の地の開拓は 順調に進んでいくだろうか.

\section{REFERENCES}

1) http://www.osakac.ac.jp/labs/tyamamot/

2) Yamamoto T, J Non-Newtonian Fluid Mech, 264, 98 (2019).

3) Yamamoto T, Nihon Reoroji Gakkaishi (J Soc Rheol Jpn), 48, 121 (2020).
4) Yamamoto T, Nihon Reoroji Gakkaishi (J Soc Rheol Jpn), 43, 53 (2015).

5) Yamamoto T, Emura C, Oya M, Comput Biol Med, 79, 173 (2016).

6) Yamamoto T, Chem Eng Jpn, 11, 569 (2020) (in Japanese).

7) Onishi T, Tsujinaka Y, Yamamoto T, J Text Eng, 67 (2021) (in Japanese) in press. 